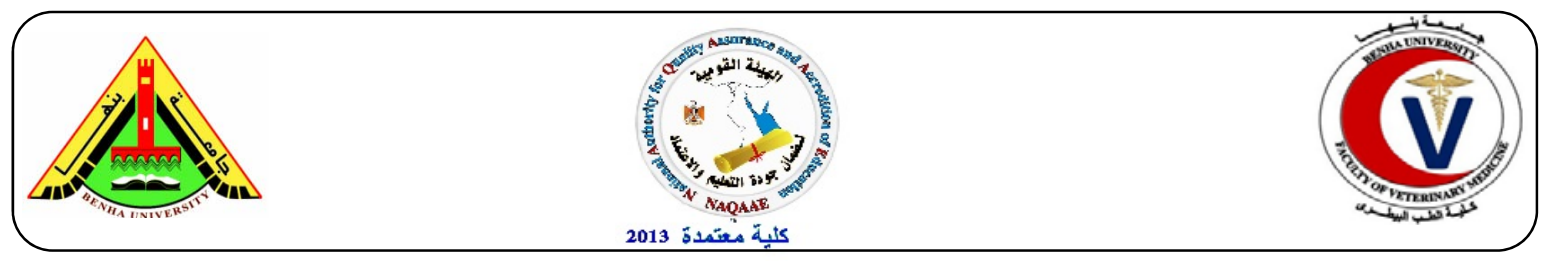

\title{
Renal protective effect of cardamom against nephrotoxicity induced by gentamicin in rats
}

\author{
Ashraf Elkomy, Mohamed Aboubakr* and Noha Elsawaf \\ Department of pharmacology, Faculty of Veterinary Medicine, Benha University, Egypt \\ *Corresponding author: mohamed.aboubakr@fvtm.bu.edu.eg.
}

\section{A B S T R A C T}

This study was conducted to evaluate the renal protective effect of cardamom against experimentallyinduced gentamicin toxicity in rats. Forty adult male Westar albino rats were randomly grouped into four groups (each of 10 rats). Rats in group (1) were orally administered saline (the vehicle) daily for 8 consecutive days and severed as control group. Group 2: were given gentamicin ( $80 \mathrm{mg} / \mathrm{kg}$. b.wt. i.p.) daily for 8 consecutive days. Group 3: were given gentamicin $(80 \mathrm{mg} / \mathrm{kg}$. b.wt. i.p.) daily for 8 consecutive days, then cardamom extract $\left(100 \mathrm{mg} / \mathrm{kg}\right.$. b.wt. p.o.) daily from $9^{\text {th }}$ to $21^{\text {th }}$ days. Group 4 : were given gentamicin $(80 \mathrm{mg} / \mathrm{kg}$. b.wt. i.p.) daily for 8 consecutive days, then cardamom extract (200 $\mathrm{mg} / \mathrm{kg}$. b.wt. p.o.) daily from $9^{\text {th }}$ to $21^{\text {th }}$ days. Gentamicin-treated rats showed significant renal damage as it increases creatinine, urea, glucose and total protein showed a significant decrease. While In groups (gentamicin + cardamom $100 \mathrm{mg} / \mathrm{kg} \&$ gentamicin + cardamom $200 \mathrm{mg} / \mathrm{kg}$ ), showed significant protection to rats kidney from structural and functional changes associated with gentamicin. Gentamicin which induced nephrotoxicity can be prevented by co-administration with cardamom.

Key wards: gentamicin, cardamom, nephrotoxicity.

(http://www.bvmj.bu.edu.eg)

(BVMJ-29(2): 100-105, 2015)

\section{INTRODUCTION}

$\mathrm{H}$

erbs and spices are being continuously used since ancient time as flavoring agent, food preservatives and remedies. Spices are rich in antioxidants (Dragland et al., 2003) and are potent inhibitors of tissue damage and inflammation. Spices and herbs in regular diet may improve to health and lower the risk of many diseases (Singh et al., 2013). Herbs and spices have antioxidant and antiinflammatory activities (Tsai et al., 2005). Cardamom, Elettaria cardamomum maton (Fam. Zingiberaceae) known as true or lesser cardamom is the widely cultivated variety and important in the world trade. It occupies a high second or third place in world trade, being a high priced spice. It belongs to the sweet spices group and is used predominantly to flavor sweets, baked goods, and coffee, particularly in the Arab countries (Govindarajan., 1982). Cardamom (is a herbaceous perennial belonging to the family Zingiberaceae. Its dried fruit is one of the highly priced spices in the world. The dried fruit is used either whole or in ground form as a flavoring agent and also in the medicinal preparations for ingestion for flatulence. The most functionally important constituent of cardamom is its volatile oil (Leela et al., 2008). In addition to its culinary uses, cardamom has been employed in traditional medicinal plants used against kidney and urinary disorders (Ballabh et al., 2008). Some studies showed that extracts and its constituents from cardamom also possess antimicrobial (Shaker., 2013, Jebur et al., 2014 \& Hammad et al., 2014), gastroprotective effects (Mutmainah et al., 2014), antidiabetic effect (Winarsi et al., 
2014), hepatoprotective activity (Kandasamy et al., 2010 \& Chacko et al., 2012), anti-hyperlipidemic (Selvan et al., 2013), Vavaiya and Patel., 2013 \& Sailesh et al., 2013) and antioxidative effects (Das et al., 2012). Aminoglycoside antibiotics are employed clinically because of their potent bactericidal activities, less bacterial resistance, post-antibiotic effects and low cost. However, drugs belong to this class are well-known to cause nephrotoxicity, which limits their frequent clinical exploitation. Gentamicin, a commonly used aminoglycoside, is associated with an induction of tubular necrosis, epithelial edema of proximal tubules, cellular desquamation, tubular fibrosis, glomerular congestion, perivascular edema and inflammation, which ultimately show the way to renal dysfunction (Noorani et al., 2011). It is a matter of debate whether we have promising agents to prevent the incidence of gentamicin-induced nephrotoxicity. The aim of the present study was to de determine the possible therapeutic approach of cardamom to prevent gentamicin-induced nephrotoxicity in rats.

\section{MATERIALS AND METHODS}

\subsection{Animals}

Forty adult male Wistar albino rats (160$190 \mathrm{~g})$ were obtained from the Animal House, Faculty of Veterinary Medicine, Benha University, Egypt. They were maintained on standard pellet diet and tap water ad libitum and were kept in plastic cages under a $12 \mathrm{hr}$ light/dark cycle and room temperature $22-24^{\circ} \mathrm{C}$. Rats were acclimatized to the environment for two week prior to experimental use. This investigation was approved by the Animal Research Ethics Committee.

\subsection{Drugs and medicinal plant used:}

Gentamicin: (Garamycin ${ }^{\circledR}$ injection), is one of aminoglycoside antibiotics. It was obtained from Memphis Company for Pharmaceutical and Chemical Industries, Cairo, Egypt. It is dispensed in the form of ampoules; each containing $40 \mathrm{mg} / \mathrm{ml}$. Rats were intra-peritoneally administered with gentamicin in a dose of $80 \mathrm{mg} / \mathrm{kg}$ to induce acute nephrotoxicity and hepatotoxicity (Noorani et al., 2011). Cardamom: (Elettaria cardmomum) fruits were purchased from the local market of Agricultural Herbs, Spices and Medicinal plants, Cairo, Egypt. The dried plant materials were grinded into a fine powder and kept till the preparation of aqueous extracts.

\subsection{Preparation of Aqueous Extract:}

Air-dried powder $(10 \mathrm{~g})$ of the respective plant seeds was mixed well in $100 \mathrm{ml}$ sterilized distilled water and kept at room temperature for $24 \mathrm{~h}$ on an orbital shaker with $150 \mathrm{rpm}$. The solution was further filtered using muslin cloth. The filtrate was centrifuged at $5000 \mathrm{rpm}$ for $15 \mathrm{~min}$. The supernatant thus obtained was filtered through Whattman filter No. 1 under strict aseptic conditions and the filtrate was collected in a pre-weighed sterilized test tube. Aqueous extracts were prepared in final concentration of $100 \mathrm{mg} / \mathrm{ml}$. Test tubes were cotton plugged and stored in refrigerator until further used (Kaushik et al., 2010).

\subsection{Experimental design:}

The rats were randomly grouped into four groups (each of 10 rats). Group 1: Rats which served as the control was orally administered saline (the vehicle) daily for 8 consecutive days. Group 2: Rats in this group were given gentamicin $(80 \mathrm{mg} / \mathrm{kg}$. b.wt. i.p.) daily for 8 consecutive days. Group 3: Rats in this group were given gentamicin $(80 \mathrm{mg} / \mathrm{kg}$. b.wt. i.p.) daily for 8 consecutive days, then Cardamom extract (100 mg/kg. b.wt. p.o.) daily from $9^{\text {th }}$ to $21^{\text {th }}$ days. Group 4: Rats in this group were given gentamicin $(80 \mathrm{mg} / \mathrm{kg}$. b.wt. i.p.) daily for 8 consecutive days, then Cardamom extract (200 mg/kg. b.wt. p.o.) daily from $9^{\text {th }}$ to $21^{\text {th }}$ days. At the end of the 3 week, blood samples were taken from all 
rats which underwent laparotomy, and experimental parameters were measured.

\subsection{Blood samples:}

Blood samples were collected $24 \mathrm{~h}$ after the end of the $21^{\text {th }}$ day. Blood was collected by retro-orbital sinus puncture from each anesthetized rats with ether. The collected blood samples were allowed to clot and serum samples were obtained by centrifugation at $3000 \mathrm{rpm}$ for $10 \mathrm{~min}$, the serum was separated immediately and stored at $-20^{\circ} \mathrm{C}$ until determination of biochemical parameters.

\subsection{Biochemical assay:}

Serum was obtained for determination of chemical parameters: creatinine, urea, glucose and total protein. Creatinine concentration in serum was determined calorimetrically by the method described by Murray (1984) using kits from Diamond Diagnostic Company (Egypt). Urea concentration in serum was determined calorimetrically by the method described by Kapla (1984) using kits from Diamond Company. Glucose concentration in serum was determined colorimetrically by the method described by Trinder (1969) using kits from Diamond Diagnostic Company (Egypt). Total protein concentration in serum was determined calorimetrically by the method described by Koller (1984) using kits from Diamond Diagnostic Company (Egypt).

\subsection{Statistical analysis:}

The data were expressed as (mean \pm SEM) and analyzed using SPSS (16) software (SPSS Inc., Chicago, USA) and differences between the averages were examined by Duncan's multiple range test. Mean values within a row with different superscript letters are significantly different $(P \leq 0.05)$ (Duncan., 1955)

\section{RESULTS}

The present study showed that the administration of gentamicin to rats once daily for 8 days reduces glomerular function. As reflected by increased serum creatinine concentrations as well as urea and glucose and decrease in total protein (Table 1). Effect of cardamom against gentamicin treatment on the previous parameters: serum urea, creatinine and glucose were decreased significantly, while serum total protein increased significantly after cardamom treatment following nephrotoxicity induced by gentamicin (Table 1).

Table (1) Nephroprotective effect of cardamam on some serum parameters in rats $(n=10)$.

\begin{tabular}{lcccc}
\hline Parameters & Control & Gentamicin & $\begin{array}{c}\text { Gentamicin } \\
+ \\
\text { Cardamom } \\
(100 \mathrm{mg})\end{array}$ & $\begin{array}{c}\text { Gentamicin } \\
+ \\
\text { Cardamom } \\
(200 \mathrm{mg})\end{array}$ \\
\hline Urea $(\mathrm{mg} / \mathrm{dl})$ & $18.49 \pm 0.75^{\mathrm{c}}$ & $30.59 \pm 1.62^{\mathrm{a}}$ & $26.71 \pm 1.12^{\mathrm{b}}$ & $22.02 \pm 1.34^{\mathrm{b}}$ \\
Creatinine $(\mathrm{mg} / \mathrm{dl})$ & $1.02 \pm 0.05^{\mathrm{c}}$ & $2.21 \pm 0.12^{\mathrm{a}}$ & $1.73 \pm 0.08^{\mathrm{b}}$ & $1.48 \pm 0.07^{\mathrm{b}}$ \\
Glucose $(\mathrm{mg} / \mathrm{dl})$ & $142.81 \pm 4.18^{\mathrm{d}}$ & $212.03 \pm 5.17^{\mathrm{a}}$ & $179.18 \pm 5.23^{\mathrm{b}}$ & $159.83 \pm 5.08^{\mathrm{c}}$ \\
& $6.99 \pm 0.31^{\mathrm{a}}$ & $5.11 \pm 0.27^{\mathrm{d}}$ & $6.24 \pm 0.32^{\mathrm{b}}$ & $5.84 \pm 0.31^{\mathrm{c}}$ \\
\hline Total protein $(\mathrm{g} / \mathrm{dl})$ & \multicolumn{3}{c}{} &
\end{tabular}

\section{DISCUSSION}

Gentamicin enhanced the production of superoxide anion, hydrogen peroxide and hydroxyl radicals by mitochondria (Yang et al., 1995). Free radicals cause Peroxidation of phospholipids membrane, DNA strand breakage, protein 
denaturation. Most significant biological damage of active metabolites is their reaction with unsaturated lipid and so their peroxidation. This effect induces changes in membrane fluidity, thus the membrane gets permeable even to molecules as large as enzymes (May and Jochen., 1990). This study evaluated kidney function by measuring serum creatinine and urea values. Gentamicin treatment is found to elevate creatinine and urea levels in serum, suggesting an impairment of kidney functions. These effects could also be attributed to the aminoglycoside induced nephrotoxicity is characterized by a decrease in the glomerular filtration rate and direct tubular injury. These observations are generally in agreement with other studies (Reiter et al., 2009) \& (Safa et al., 2010). Creatinine and urea are waste products of protein metabolism that need to be excreted by the kidney, therefore a marked increase of these parameters, as observed in this study, confirms an indication of functional damage to the kidney (Panda et al., 2009). Urea level can be increased by many other factors such as dehydration, antidiuretic drugs and diet, while creatinine is more specific to the kidney, since kidney damage is the only significant factor that increases the serum creatinine level (Cheesbrough., 1998). However, administration of cardamom along with gentamicin caused significant decrease in urea and creatinine suggested the protective effects of cardamom. This results agreed with Verma et al., (2015) who reported a significant reduction in blood urea nitrogen and serum creatinine after beneficial effect of alcoholic seed extract of A. cardamomum in alloxan induced diabetic rats due to improvement on glomerular function of kidney and maintained positive nitrogen balance (Sabu and Kuttan., 2002). Also there was a significant increase in levels of serum glucose levels in gentamicin treated group as compared to control group. However, administration of cardamom following gentamicin caused significant decrease in levels of serum of glucose as compared to gentamicin groups suggested the prophylactic roles of cardamom. The lowering effect of cardamom on glucose level was observed by El-Yamani (2011), who studied the hypoglycemic effect of cardamom as one of spices that possess antioxidant compounds. In the present study, there was a significant decrease in the concentration of serum total protein in gentamicin group as compared to control group, might be depressed as a result of defective protein synthesis. However, administration of cardamom along with gentamicin caused significant increase in total protein suggested the protective effects of cardamom. Verma et al., (2015) reported an increase in total protein concentrations after oral administration of alcoholic seed extracts of $A$. cardamomum due to stimulation of number of m-RNA molecule the attachment with ribosome (Rao and Nammi., 2006).

In Conclusion, oral administration of cardamom watery extract produces significant renal protective effect. Its antioxidant properties reduce kidney damage caused by gentamicin.

\section{REFERENCES}

Ballabh, B., Chaurasia, O.P., Ahmed, Z., Singh, S.B. 2008. Traditional medicinal plants of cold desert Ladakh-used against kidney and urinary disorders. J. Ethnopharmacol, 118(2-3): 331-339.

Chacko, N., Thomas, A., Shastry, C.S., Shetty, P. 2012. Hepatportective activity of (Elettaria cardamomum) against paracetamol induced hepatotoxicity. Int. J. Pharm \& Pharm. Sci, 4(3): 611-613.

Cheesbrough, M. 1998. Clinical chemistry tests. In: District laboratory practice in tropical countries. Cambridge new edition, part I: 331-363.

Das, L., Acharya, A., Berry, D.L., Sen, S., Williams, E., Permaul, E., 
Senguptaa1, A., Bhattacharyaa, S., Sahaa, T. 2012. Anti-oxidative effects of the spice cardamom against nonmelanoma skin cancer by modulating nuclear factor erythroid-2-related factor 2 and NF- $\kappa \mathrm{B}$ signalling pathways. Br. J. Nutr, 108(6): 984997.

Dragland, S., Senoo, H., Wake, K., Holte, k., Blomhoff, R. 2003. Several culinary and medicinal herbs are important sources of dietary antioxidants. J. Nutr. 133: 1286-1290.

Duncan, D.B. 1955. Multiple range and multiple F tests. Biometrics, 11(1): 142.

El-Yamani, M.A. 2011. Cinnamon, cardamom and ginger impacts as evaluated on hyperglycemic rats. Res. J. Spec. Edu. Mansoura Uni. 20: 664679.

Govindarajan, V.S., Narasimhan, S., Raghuveer, K.G., Lewis, Y.S. 1982. Cardamom--production, technology, chemistry, and quality.Crit. Rev. Food. Sci. Nutr. 16(3): 229-326.

Hammad, A.Y., Eltegani, S.E., Abdelgadir, W.S. 2014. Comparative in vitro antimicrobial activity of (Elettaria cardamomum) fruit and Mentha spicata leaves. Eur. J. Bio. \& Pharm. Sci. 1(3): 37-45

Harries, M.L. 1989. Carleton's Histopathological Technique: $5^{\text {th }}$ Ed. Oxford Univ Press, New York, Toronto, 33-48.

Jebur, M.H., Dr. Bnuyan, I., Dr. Yasri, A.A., Dr. Hindi, N.K.K. 2014. Antimicrobial effect of seed extracts, leaves and crude oil of cardamom. (Elettaria cardamomum) against different types of bacteria in Hilla City, Iraq. W. J. Pharm. Res. 3(3): 4934-4944.

Kandasamy, C.S., Basil, M., Thasnim, P.S.S., Siva, K.R., Gopal, V., Venkatnarayanan, R. 2010. Hepatoprotective activity of polyherbal formulation containing some indigenous medicinal plants in rats. Res. J. Pharm. and Tech. 3(3): $828-831$.

Kaplan, A. 1984. Uric acid. Clin. Chem. The C.V Mosby Co. St. Louis. Toronto. Princeton. 1257-1260 and 418 and 437.

Kaushik, P., Goyal, P., Chauhan, A., Chauhan, G. 2010. In vitro evaluation of antibacterial potential of dry fruit extracts of (Elettaria cardamomum maton) (Chhoti elaichi). Iran. J. Pharm. Res. 9: 287-292.

Khalaf, N.A., Shakya, A.K., Al-Othman, A., El-Agbar, Z., Farah, H. 2008. Antioxidant activity of some common plants. Turk. J. Biol. 32: 51-55

Koller, A. 1984: Total serum protein. Clin. Chem. The C.V. Mosby Co. St Louis. Toronto. Princeton. 1316-1324.

Leela, N.K., Prasath, D., Venugopal, M.N. 2008. Essential oil composition of selected cardamom genotypesat different maturity levels. Ind. J. Horticulture 65: 366-369.

May, Y.H., Jochen, S. 1990. Formation of a cytotoxic metabolite from gentamicin by liver. Bio. Pharmacol. 40(11): 1114.

Murray, R.L. 1984. Creatinine. Clin. Chem. The C.V. Mosby Co. St Louis. Toronto. Princeton. 12611266 and 418.

Mutmainah., Susilowati, R., Rahmawati, N., Nugroho, A.E. 2014. Gastroprotective effects of combination of hot water extracts of turmeric (Curcuma domestica l.), cardamom pods (Ammomum compactum s.) and sembung leaf (Blumea balsamifera dc.) against aspirin-induced gastric ulcer model in rats. Asian. Pac. J. Trop. Biomed. 4(1): 500-504.

Noorani, A., Gupta, K., Bhadada, K., Kale, M.K. 2011. Protective effect of methanolic leaf extract of Caesalpinia bonduc (l.) on gentamicin-induced hepatotoxicity and nephrotoxicity in rats. Iran. J. Pharm. 10: 21-25. 
Panda, N.C. 2009. Kidney In: Textbook of Biochemistry and Human biology. second ed., Prentise hall India. 290296.

Rao, N.K., Nammi, S. 2006. Antidiabetic and renoprotective effects of the chloroform extract of Terminalia chebularetz seeds in streptozotocininduced diabetic rats. BMC Comp. Med. 6: 17-24.

Reiter, M., Rupp, K., Baumeister, P., Zieger, S., Harreus, U. 2009. Antioxidant effects of quercetin and coenzyme Q10 in mini organ cultures of human nasal mucosa cells. Antican. Res. 29: 33-40.

Sabu, M.C., Kuttan, R. 2002. Antidiabetic activity of medicinal plants and its relationship with their antioxidant properties. J. Ethnopharmacol. 81: 155-160.

Safa, J., Argani, H., Bastani, B., Nezami, N., Ardebili, B.R., Ghorbanihaghjo, A., Kalagheichi, H., Amirfirouzi, A., Mesgari, M., Rad, J.S. 2010. Protective effect of grape seed extract on gentamicin- induced acute kidney injury. Iran. J. Kid. Dis. 4: 285-291.

Sailesh, K.S., Divya., Mukkadan, J.k. 2013. A study on anti-hyper lipidemic effect of oral administration of cardamom in wistar albino rats. Narayana. Med. J. 2(1): 31-39.

Selvan, A.T., Suthakaran, R., Sandeep, J., Navya, P., Kumar, M.K., Gangamatha, P., Prakash, A.C. 2013. Phytochemical and pharmacological validation of the polyherbal extract on rodents. Int. J. Med. Sci. and Biotechnol. I (II): 33-40.

Shaker, N. 2013. Antibacterial effect of cardamom and black tea aqueous extract on Mutans streptococci in comparison to chlorhexidine (in vitro study). J. Bag. Coll. Dentistry. 25(3): 158-164.
Singh, D., Ram, T.C., Astava, A.K.S., Roy, B.K. 2013. Free radicals, antioxidants and culinary spices: in human health and disease response. Int. J. Bot. \&Res. 3(3): 1-14.

Trinder, P. 1969. Determination of glucose in blood using glucose oxidase with an alternative oxygen acceptor. Ann. Clin. Biochem. 6: 24-27.

Tsai, T. H., Tsai, P. J., Ho, S. C. 2005. Antioxidant and anti-inflammatory activities of several commonly used spices. J. Food. Sci.70: 93-97.

Vavaiya, R.B., Amit, P., Manek, R.A. 2012. Anti-diabetic activity of (Amomum subulatum roxb). fruit constituents. int. J. pharm. innov. 2(5): 50-63.

Vavaiya, R.B., Patel, A.A. 2013. Evaluation of anti-hyperlipidemic activity of (Ammomum subulatum) seeds extracts. Int. J. pharm. innov. 3(4): 97-102.

Verma, D., Yadav, R., Kumar, M. 2015. Effect of seed extract of (Amomum cardamomum) on renal function in alloxan induced diabetic rats. W. J. Clin. Pharm, Micr and Toxi. 1(1): 5254.

Winarsi, H., Sasongko, N.D., Purwanto, A., Nuraeni, I. 2014. Effect of cardamom leaves extract as antidiabetic, weight lost and hypocholesterolemia to alloxan-induced sprague dawley diabetic rats. Int. Food. Res. J. 21(6):2253-2261.

Yang, C., Du, X., Han, Y. 1995. Renal cortical mitochondria are the source of oxygen free radicals enhanced by gentamicin. Ren. Fail. 17: 21-26.

Zhihua, Z., Jianping, Y., Miaomiao, S., Kuisheng, $\quad$ C. 2014. Exploration for the multi-effect of cardamom in's resistance to multiple myeloma. Pak. J. Pharm. Sci. 27(6): 2001-2006. 